\title{
Classification of clinical risk in people with AIDS followed up in specialized care
}

\author{
Classificação de risco clínico em pessoas com aids acompanhadas na atenção especializada \\ Clasificación de riesgo clínico en personas con SIDA acompañadas de la atención especializada
}

'Universidade Federal da Paraíba. João Pessoa, Paraíba, Brazil.

"Universidade de São Paulo, Escola de Enfermagem de Ribeirão Preto. Ribeirão Preto, São Paulo, Brazil.

How to cite this article:

Leadebal ODCP, Medeiros LB, Nascimento JA, Monroe AA, Nogueira JA. Classification of clinical risk in people with AIDS followed up in specialized care. Rev Bras Enferm. 2018;71(5):1235-42. doi: http://dx.doi.org/ 10.1590/0034-7167-2017-0559

Corresponding Author:

Oriana Deyze Correia Paiva Leadebal E-mail: orianadcpl@gmail.com

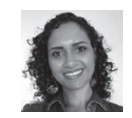

Submission: 08-04-2017

Approval: 12-19-2017

\begin{abstract}
Aim: To develop a clinical risk stratification score for people living with AIDS and to analyze its association with clinical and sociodemographic aspects. Method: Cross-sectional study involving 150 adults with AIDS, in outpatient follow-up. A structured instrument was applied and, sequentially, inferential statistical techniques on the developed score. Results: $45.3 \%$ of the participants were classified as in high clinical risk. TL-CD4+<500cel $/ \mathrm{mm}^{3}$ count, detectable viral load, presence of opportunistic diseases, chronic diseases and clinical manifestations were associated with high clinical risk. There was a significant difference in the mean risk between the categories of variables employment status $(p=0.003)$ and economic class $(p=0.035)$. There was a higher risk for brown people $(O R=5.55)$, unemployed status $(O R=16,51)$ and belonging to classes $C(O R=20.07)$ and $D(O R=53,32)$, and a lower risk for individuals with higher schooling $(\mathrm{OR}=0.02)$. Conclusion: The proposed score quantifies clinical situations and points out sociodemographic aspects that predispose to instability and aggravation of AIDS, supporting the qualification of care.
\end{abstract}

Descriptors: Nursing; Acquired Immunodeficiency Syndrome; Outpatient Care; Risk Assessment; Technology.

\section{RESUMO}

Objetivo: Elaborar um escore para estratificação de risco clínico de pessoas vivendo co.m Aids e analisar sua associação com aspectos clínicos e sociodemográficos. Método: Estudo transversal envolvendo 150 adultos com aids, em acompanhamento ambulatorial. Aplicouse instrumento estruturado e, sequencialmente, técnicas estatísticas inferenciais sobre o escore elaborado. Resultados: $45,3 \%$ dos participantes foram classificados no risco clínico alto. A contagem de LT-CD4+ $<500$ cel $/ \mathrm{mm}^{3}$ carga viral detectável, presença de doenças oportunistas, doenças crônicas e manifestações clínicas associaram-se ao risco clínico elevado. Verificou-se diferença significativa no risco médio entre as categorias das variáveis situação empregatícia $(p=0,003)$ e classe econômica $(p=0,035)$. Constatou-se maior risco para pessoas pardas $(O R=5,55)$, afastadas do emprego $(O R=16,51)$ e pertencentes às classes $C(O R=20,07)$ e $D(O R=53,32)$, e menor risco entre os indivíduos com maior escolaridade $(\mathrm{OR}=0,02)$. Conclusão: $\mathrm{O}$ escore proposto quantifica situações clínicas e aponta aspectos sociodemográficos que predispõem a instabilidade e agudização da aids, subsidiando a qualificação do cuidado.

Descritores: Enfermagem; Síndrome de Imunodeficiência Adquirida; Assistência ambulatorial; Determinação do Risco; Tecnologia.

\section{RESUMEN}

Objetivo: Elaborar una puntuación para estratificación de riesgo clínico de personas viviendo con sida y analizar su asociación con aspectos clínicos y sociodemográficos. Método: Estudio transversal que involucra a 150 adultos con sida, en seguimiento de ambulatorio. Se aplicó instrumento estructurado $y$, secuencialmente, técnicas estadísticas que interfieren en la puntuación elaborada. Resultados: El 45,3\% de los participantes fueron clasificados en el riesgo clínico alto. La cuenta de LT-CD4+<500cel/ $\mathrm{mm} 3$, la carga viral detectable, la presencia de enfermedades oportunistas, las enfermedades crónicas y manifestaciones clínicas se asociaron al riesgo clínico elevado. Se verificó una diferencia significativa en el riesgo medio entre las categorías de variables de empleo $(p=0,003)$ y la clase económica $(p=0,035)$. Se constató un mayor riesgo para las personas pardas $(\mathrm{OR}=5,55)$, alejadas del empleo $(\mathrm{OR}=16,51)$ y pertenecientes a las clases $C(O R=20,07)$ y $D(O R=53,32)$, y menor riesgo entre los individuos con mayor escolaridad $(\mathrm{OR}=0,02)$. Conclusión: La puntuación propuesta cuantifica situaciones clínicas y apunta aspectos sociodemográficos que predisponen a la inestabilidad y agudización del sida, subsidiando la calificación del cuidado. Descriptores: Enfermería; Síndrome de Inmunodeficiencia Adquirida; Atención Ambulatoria; Medición de Riesgo; Tecnología. 


\section{INTRODUCTION}

Organizing the healthcare network for users with chronic conditions requires a service offer that is planned according to different criteria of needs. Risk stratification has been recommended because it allows for individualized care, both in their nature and frequency, and because it allows defining the types of attention and their concentration relative to each health condition in the clinical guidelines ${ }^{(1)}$.

In the case of AIDS, free and universal access to antiretroviral therapy (ART) and the possibility of monitoring the progression of the disease with the emergence of laboratory markers, such as CD4 counts and viral load tests, established a new phase of the disease, shifting from an acute to a chronic condition. Changes in the clinical course of the disease, reduced mortality and increased survival redefined the experience of living with a chronic condition and required redirection of practices and inclusion of new modes of care $^{(2-4)}$. In the context of specialized care, care models and protocols were created with a view to ensuring universal access to early diagnosis and timely treatment, rapid identification of opportunistic manifestations for an appropriate clinical management, and reduction of side and adverse effects of ART.

At present, however, the achievement of global goals of disease control requires efforts in the field of care management beyond the institution of drug therapy, focusing on the intensification of diagnosis and provision of permanent care ${ }^{(5)}$. Moreover, service coverage is inadequate, the rate of expansion is very slow, and access to care is not timely. Globally, 17 million of the 37 million people living with HIV at the end of 2016 were unaware of their HIV status, and 22 million had no access to ART. In Brazil, that same year, 48,000 new cases of HIV infection were reported. Of these, only $60 \%$ were on treatment ${ }^{(6)}$.

The need for intervention on this phenomenon and the confrontation of the epidemic require interdisciplinary and interprofessional attention to meet the health demands of these users, as well as the use of care technologies capable of subsidizing, in the clinical and managerial context, the provision of continuous care based on the knowledge of characteristics and needs of health care ${ }^{(1)}$.

In the clinical context, timely identification and intervention in conditions that result in clinical instability and exacerbations from viral pathogenesis and drug toxic effects can minimize failures in virological suppression, reducing the risk of opportunistic infections and coinfections recognized as main causes of hospitalization and deaths, even after $\mathrm{ART}^{(3)}$. In the managerial context, the use of care technologies can rationalize the mobilization of resources and the establishment of flows in Health Care Networks (RAS), according to the clinical complexities and specificities of the cases $^{(1)}$, especially in a perspective of prevention of the clinical instabilities associated with HIV/AIDS.

In this direction, risk stratification is characterized as a potential strategy to direct actions and flows towards the provision of universal, equanimous and efficient care ${ }^{(1,5,7)}$. Since health professionals of specialized services - among them nurses - are playing an important role in monitoring the treatment and management of clinical instability, exacerbations, and situations of vulnerability to death associated with HIV/AIDS, the use of risk stratification will favor the qualification of care, demanding a greater theoretical basis to encourage the creation of instruments sensitive to the inherent specificities of infection/illness/treatment.

\section{OBJECTIVE}

To develop a score for stratification of clinical risk of people living with AIDS and to analyze its association with clinical and sociodemographic aspects.

\section{METHOD}

\section{Ethical aspects}

The study was approved by the Research Ethics Committee of the Health Sciences Center of the Federal University of Paraíba, in accordance with Resolution 466/12 of the National Health Council, which provides for the development of research involving human beings. Participants signed the Informed Consent Form, were informed about the aims, risks and benefits of the study and were guaranteed anonymity, privacy and the possibility of withdrawing from the study at any time, without prejudice.

\section{Design, place of study}

A cross-sectional study developed in an outpatient clinic specialized in the care of people living with HIV/AIDS in Paraíba, integrated into a state reference unit for the treatment of infectious and parasitic diseases, located in the capital, João Pessoa, and offering outpatient and hospital care.

\section{Population and sample; inclusion and exclusion criteria}

The population considered for the calculation of sample size was composed of 1,260 people with AIDS notified in the Information System for Notifiable Diseases from 1980 to June 2011, aged over 18 years and residing in the state of Paraíba. A 95\% confidence level, sample error of $8 \%$, population proportion of $50 \%$ and correction for potential loss of $10 \%$ were assumed, reaching the sample size of 150 participants.

Using a non-probabilistic sampling technique, participants were recruited by chance during routine outpatient visits, considering the following inclusion criteria: subjects of both sexes, using ART for a period of six months or more. Individuals in situations of deprivation of liberty and pregnant women were excluded from the study due to the inherent specificities of the clinical management of these populations and the organization of the local attention network.

\section{Study Protocol}

Data collection was carried out between July 2011 and July 2012 , with the technique of interview and consultation of medical records. A structured form was used with information on the clinical variables (T-CD4/CD8 lymphocytes count, viral load, number of opportunistic diseases, number of chronic diseases and number of clinical manifestations) and sociodemographic variables (gender, age, color, marital status, schooling, employment status, economic classification, sexual orientation, transmission category). The classification criteria of the Brazilian Association of Survey Companies was used for economic classification of the population ${ }^{(8)}$. 
The instrument was previously submitted to content validation by the Group of Operational Studies in HIV/AIDS of the Nursing School of Ribeirão Preto and to the reliability analysis performed using the Cronbach alpha coefficient, whose result $(=0.789)$ confirmed that there is internal consistency and equilibrium of the participation of the variables in its composition. This instrument was adapted to the local reality and submitted to a pilot study with ten participants, who did not compose the sample.

The interviews were conducted by a previously trained team and carried out in the institution's premises with an average duration of 35 minutes. The medical records were accessed shortly after the medical appointments.

\section{Analysis of results and statistics}

Data was entered (double entry) into a Microsoft Office Excel 2003 spreadsheet, transferred and stored in StatSoft's Statistica 9.0 software, and analyzed using descriptive and inferential statistics techniques with $95 \%$ confidence intervals and hypothesis tests with level of significance of $5 \%$.

For the sociodemographic and clinical characterization of the participants, frequency and distribution measures according to the risk stratification were used. For risk stratification, indicators 1, 2 and 3 were attributed to the values of T-CD4+/CD8 (TL-CD4+) lymphocytes, viral load (VL), number of opportunistic diseases, number of chronic diseases and number of clinical manifestations of each participant, considering the predictive laboratory and clinical parameters of prognosis, response to HAART, magnitude for main opportunistic conditions and clinical complications ${ }^{(2)}$. Positive parameters were assigned with the lowest value ${ }^{(1)}$ and the negative ones the highest value ${ }^{(3)}$. The variable categorized risk (sum total of the indicators of the five variables) was sequentially calculated, whose values ranged from 5 to 14 , considering low risk $=5$, medium risk $=6$ and high risk $>6$ (Chart 1$)$.

Chart 1 - Categories and criteria of clinical risk

\begin{tabular}{|c|l|}
\hline Risk & \multicolumn{1}{|c|}{ Classification criteria } \\
\hline $\begin{array}{c}\text { Low } \\
\text { (low clinical } \\
\text { complexity) } \\
\text { (risk }=5)\end{array}$ & $\begin{array}{l}\text { TL-CD4+ } 500 \text { cel/mm } \mathrm{mm}^{3}(=1)+\text { undetectable VL } \\
(=1)+\text { no opportunistic disease }(=1)+\text { no chronic } \\
\text { disease }(=1)+\text { no sign or symptom }(=1)\end{array}$ \\
\hline $\begin{array}{c}\text { Medium } \\
\text { (medium clinical } \\
\text { complexity) } \\
\text { (risk=6) }\end{array}$ & $\begin{array}{l}\text { TL-CD4+ between } 200 \text { and } 500 \text { cel/ } \\
\mathrm{mm}^{3}(=2)+\text { undetectable VL }(=1)+\text { no } \\
\text { opportunistic disease }(=1)+\text { no chronic } \\
\text { disease }(=1)+\text { no sign or symptom }(=1)\end{array}$ \\
\hline $\begin{array}{c}\text { High } \\
\text { (high clinical } \\
\text { complexity) } \\
\text { (risk }>6)\end{array}$ & $\begin{array}{l}\text { TL-CD4+<200 cel/mm3 }(=3)+\text { detectable VL }(=2) \\
+ \text { no opportunistic disease }(=1) \text { or occurrence of } \\
\text { an opportunistic disease }(=2) \text { or two opportunistic } \\
\text { diseases }(=3)+\text { occurrence of a chronic disease }(=2) \\
\text { or two chronic diseases }(=3)+\text { occurrence of } 2 \text { or } \\
\text { more }(=2) \text { signs and symptoms }(=3)\end{array}$ \\
\hline
\end{tabular}

Note: TL-CD4+: Tlymphocytes CD4+/CD8); VL: Viral load.

For composing the proposed score, all clinical variables were considered, and the quantification of TL-CD4+ was the priority indicator in the determination of this measure, considering the multiple correspondence analysis applied to analyze the association between clinical risk and its influential variables. Through this analysis we obtained in dimension 1 the percentage of 43.7 of the total inertia, and a more acceptable measure of reliability (Cronbach's alpha $=0.742$ ) in relation to dimension $2(24.8 \%$ of total inertia), with explanatory power of both reaching $68.5 \%$.

For the analysis of contributions of the component variables in the construction of the dichotomized risk score, the logistic regression model was applied, with a dependent variable $y=$ risk, where risk-free $y=0$, and y with risk $=1$; whose general test for nullity of parameters presented $p$-value $(<0.05)$ desirable for its use; Nagelkerke $R^{2}(=0.99)$ with a value close to 1 ; HosmerLemeshow test ( $p$-value $>0.05$ ) accepting the hypothesis of adequacy of the data to the model; obtaining in the matrix of classification a hit percentage of $99.8 \%$.

Considering that, according to the Levene test ( $p$-value $<0.05$ ), heterogeneity occurred, and according to the Komorgorov-Smirnov test ( $p$-value $<0.001$ ), the dependent variable risk did not present normal distribution, we used Robust Variance Analysis ( $f$ of ANOVA ) or t-test to check the significance of socio-demographic factors and those related to the clinical follow-up of the users on clinical risk. In situations where there was a significant result in the ANOVA model, we used the multiple comparisons of the factor categories through the Tukey test.

The influence of factors on risk was observed using the logistic regression model, with outcome variable categorized clinical risk presented in dichotomous form as present $(=1)$ and absent $(=0)$. The general test for nullity of the parameters was rejected ( $p$-value $<0.001)$, a basic condition for application of the model (omnibus tests ); Nagelkerke $\mathrm{R}^{2}(68.0 \%)$ affirmed the degree of fit of the model to the data on a 0-100 scale; the Hosmer-Lemeshow test ( $p$-value $=0.490$ ) showed that the model predicts a classification close to that observed by the actual risk; and the degree of accuracy in the classification matrix (confusion matrix) was $86.2 \%$.

\section{RESULTS}

Most of the participants were male (58.0\%), 40-59 years of age (48.7\%), brown skin color (58.7\%), unmarried (54.7\%), heterosexual (68.5\%), schooling up to elementary school (65.4\%), retirees/ pensioners (42.0\%) and economic class C (55.3\%).

Regarding the clinical profile, there was a prevalence of sexual transmission (68.7\%), search for diagnosis after appearance of signs and symptoms (53.3\%), mean treatment time of 5.3 years ( \pm 3.8) (minimum $=0.5$, maximum $=19$ ), with follow-up exclusively through SUS services (98.0\%); presenting at the time of interview TL-CD4+ counts higher than 500 cells $/ \mathrm{mm}^{3}$ (44.7\%), undetectable VL (76.7\%), no opportunistic diseases (88.7\%), no chronic disease (66.7\%) or clinical manifestations of any sort (70.7\%).

Considering the distribution of participants according to clinical variables and risk classification (Table 1), it was found that $45.3 \%$ were classified as high risk (score $>6$ ) and $34.0 \%$ of medium risk (score $=6$ ). We identified a significant association between the risk and the variables investigated ( $p$-value $<0.05$ ) and Somers' $d$ statistic, which measures the strength of this association on a scale from -1 to 1 , showed that all values are between 0.3 and 0.6 , characterizing a positive association (Table 1 ). 
Table 1 - Distribution of participants according to clinical variables and risk classification, João Pessoa, Paraíba, Brazil, 2012

\begin{tabular}{|c|c|c|c|c|c|c|c|c|c|c|c|}
\hline & & & Clas & sificat & on of ris & & & & & & \\
\hline Variables & & & $I=5$ & Med & $\mathrm{Im}=6$ & Hig & $h>6$ & & tal & $p$ value & Somers $d$ \\
\hline & & $\mathbf{n}$ & $\%$ & $\mathbf{n}$ & $\%$ & $n$ & $\%$ & $\mathbf{n}$ & $\%$ & & \\
\hline LT-CD4+ & $>500$ & 31 & 20.7 & 27 & 18.0 & 9 & 6.0 & 67 & 44.7 & $<0.001$ & 0.651 \\
\hline & $200-500$ & - & - & 24 & 16.0 & 41 & 27.3 & 65 & 43.3 & & \\
\hline & $<200$ & - & - & - & - & 18 & 12.0 & 18 & 12.0 & & \\
\hline VL & Undetectable & 31 & 20.7 & 49 & 32.7 & 35 & 23.3 & 115 & 76.7 & $<0.001$ & 0.654 \\
\hline & Detectable & - & - & 2 & 1.3 & 33 & 22.0 & 35 & 23.3 & & \\
\hline Opportunistic & No & 31 & 20.7 & 49 & 32.7 & 53 & 35.3 & 133 & 88.7 & $<0.006$ & 0.509 \\
\hline diseases & One & - & - & 2 & 1.3 & 14 & 9.3 & 16 & 10.7 & & \\
\hline & Two & - & - & - & - & 1 & 0.7 & 1 & 0.6 & & \\
\hline Chronic & None & 31 & 20.7 & 33 & 22.0 & 36 & 24.0 & 100 & 66.7 & $<0.001$ & 0.395 \\
\hline diseases & One & - & - & 18 & 12.0 & 23 & 15.3 & 41 & 27.3 & & \\
\hline & Two & - & - & - & - & 9 & 6.0 & 9 & 6.0 & & \\
\hline Clinical & None & 31 & 20.7 & 46 & 30.7 & 29 & 19.3 & 106 & 70.7 & $<0.001$ & 0.605 \\
\hline Manifestations & One & - & - & 5 & 3.3 & 23 & 15.3 & 28 & 18.7 & & \\
\hline & Two or more & - & - & - & - & 16 & 10.7 & 16 & 10.7 & & \\
\hline Total & & 31 & 20.7 & 51 & 34.0 & 68 & 45.3 & 150 & 100.0 & & \\
\hline
\end{tabular}

Note: TL-CD4+:Tlymphocytes CD4+/CD8; VL: Viral load
MEDIUMCD4), detectable VL (DETECVL), one or more opportunistic diseases (indicators 2 and 3 ), one or more chronic diseases (indicators 2 and 3 ) and one or more clinical manifestations (indicators 2 and 3 ) are indicators that are associated with higher clinical risk stratification (high risk).

As for the association between risk and sociodemographic variables (Table 2), the ANOVA f test showed significant differences in the mean risk between job situation categories ( $p$-value $=0.003)$ and economic class ( $p$-value $=0.035)$. Through the Tukey test it was found that the sick leave group (employment situation) and economic class E presented the highest mean risks and that the employed/ self-employed groups and social class $B$ presented lower values of mean risks (Table 2).

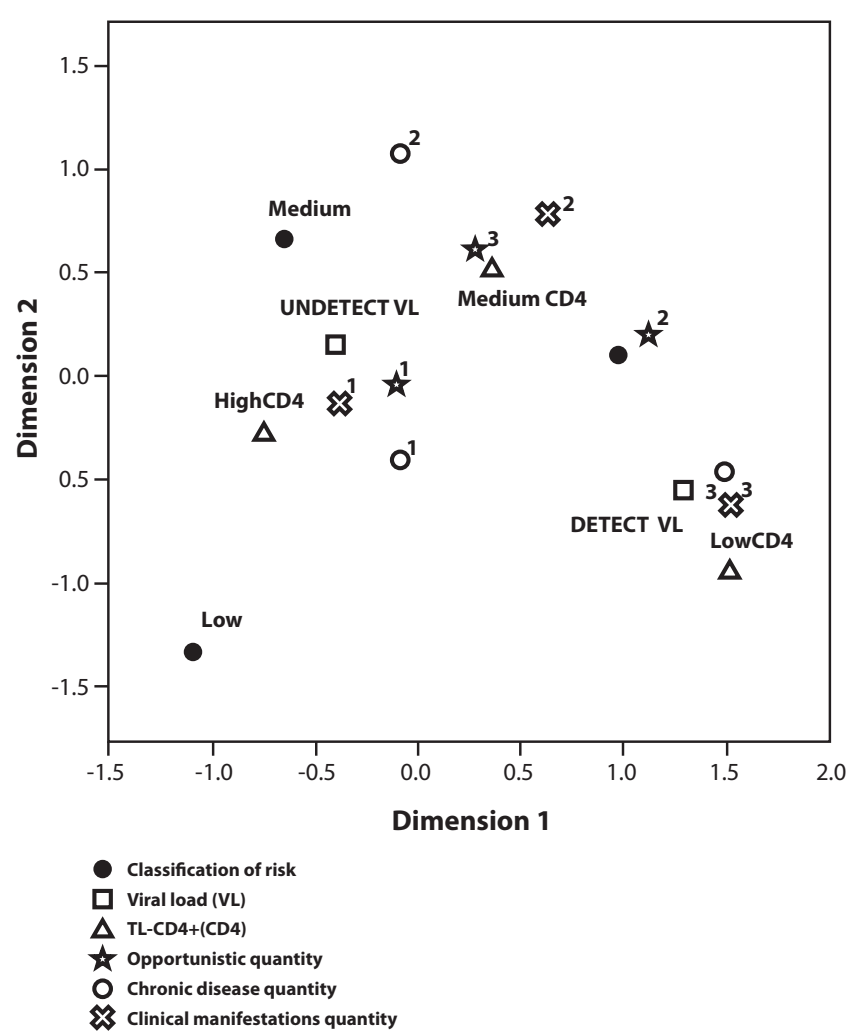

Figure 1 - Association of multiple correspondence analysis for the clinical risk and its influential variables, João Pessoa, Paraíba, Brazil, 2012

By analyzing dimension 1 (greater explanatory power) of the association diagram (Figure 1) produced by the multiple correspondence analysis, it is observed, by the proximity of the variables, that TL-CD4+ count below 500cel/mm 3 (LOWCD4 and
Table 2 - Descriptive statistics of risk in factors and comparison of their categories by means of one-way ANOVA and t-test, João Pessoa, Paraíba, Brazil, 2012

\begin{tabular}{|c|c|c|c|c|c|c|}
\hline & Factor/Category* & $\mathbf{n}$ & $\%$ & Mean & SD & $\begin{array}{c}p \\
\text { value }^{\dagger}\end{array}$ \\
\hline Sex & $\begin{array}{l}\text { Male } \\
\text { Female }\end{array}$ & $\begin{array}{l}87 \\
63\end{array}$ & $\begin{array}{l}58.0 \\
42.0\end{array}$ & $\begin{array}{l}6.8 \\
6.9\end{array}$ & $\begin{array}{l}1.5 \\
1.7\end{array}$ & 0.549 \\
\hline Age range & $\begin{array}{l}18-39 \\
40-59 \\
60-71\end{array}$ & $\begin{array}{l}68 \\
73 \\
09\end{array}$ & $\begin{array}{l}45.3 \\
48.7 \\
06.0\end{array}$ & $\begin{array}{l}6.7 \\
6.9 \\
6.4\end{array}$ & $\begin{array}{l}1.6 \\
1.7 \\
1.3\end{array}$ & 0.618 \\
\hline Skin color & $\begin{array}{l}\text { White } \\
\text { Black } \\
\text { Brown }\end{array}$ & $\begin{array}{l}41 \\
18 \\
88\end{array}$ & $\begin{array}{l}27.3 \\
12.0 \\
58.7\end{array}$ & $\begin{array}{l}6.9 \\
7.0 \\
6.7\end{array}$ & $\begin{array}{l}1.7 \\
2.1 \\
1.4\end{array}$ & 0.784 \\
\hline Marital status & $\begin{array}{l}\text { Single } \\
\text { Married/Common-law marriage } \\
\text { Separated/divorced } \\
\text { Widowed }\end{array}$ & $\begin{array}{l}82 \\
47 \\
16 \\
05\end{array}$ & $\begin{array}{c}54.7 \\
31.3 \\
10.7 \\
3.3\end{array}$ & $\begin{array}{l}6.9 \\
6.7 \\
6.4 \\
6.4\end{array}$ & $\begin{array}{l}1.8 \\
1.4 \\
1.3 \\
1.5\end{array}$ & 0.498 \\
\hline Schooling & $\begin{array}{l}\text { No schooling } \\
\text { Elementary } \\
\text { High school } \\
\text { College }\end{array}$ & $\begin{array}{l}08 \\
80 \\
49 \\
13\end{array}$ & $\begin{array}{c}5.3 \\
53.3 \\
32.7 \\
8.7\end{array}$ & $\begin{array}{l}7.5 \\
6.7 \\
7.1 \\
6.3\end{array}$ & $\begin{array}{l}1.9 \\
1.3 \\
1.9 \\
1.6\end{array}$ & 0.314 \\
\hline $\begin{array}{l}\text { Employment } \\
\text { status }\end{array}$ & $\begin{array}{l}\text { Employed/Self-employed } \\
\text { Retired/pensioner } \\
\text { Sick leave } \\
\text { Unemployed } \\
\text { Other }\end{array}$ & $\begin{array}{l}37 \\
63 \\
13 \\
25 \\
12\end{array}$ & $\begin{array}{c}24.7 \\
42.0 \\
8.7 \\
16.7 \\
8.0\end{array}$ & $\begin{array}{l}6.1 \\
6.7 \\
7.8 \\
7.4 \\
7.5\end{array}$ & $\begin{array}{l}1.1 \\
1.6 \\
1.9 \\
1.7 \\
1.4\end{array}$ & 0.003 \\
\hline $\begin{array}{l}\text { Economic } \\
\text { class }\end{array}$ & $\begin{array}{l}\text { B } \\
\text { C } \\
D \\
E\end{array}$ & $\begin{array}{l}19 \\
83 \\
37 \\
10\end{array}$ & $\begin{array}{c}12.7 \\
55.3 \\
24.7 \\
6.7\end{array}$ & $\begin{array}{l}6.3 \\
6.7 \\
6.9 \\
8.1\end{array}$ & $\begin{array}{l}1.7 \\
1.5 \\
1.5 \\
2.0\end{array}$ & 0.035 \\
\hline $\begin{array}{l}\text { Sexual } \\
\text { orientation }\end{array}$ & $\begin{array}{l}\text { Heterosexual } \\
\text { Homosexual } \\
\text { Bisexual } \\
\text { Unknown }\end{array}$ & $\begin{array}{l}102 \\
29 \\
17 \\
44\end{array}$ & $\begin{array}{l}68.5 \\
19.5 \\
11.4 \\
29.3\end{array}$ & $\begin{array}{l}6.8 \\
7.0 \\
6.4 \\
6.8\end{array}$ & $\begin{array}{l}1.5 \\
1.8 \\
1.5 \\
1.5\end{array}$ & 0.444 \\
\hline \multirow[t]{2}{*}{ Transmission } & $\begin{array}{l}\text { Sexual } \\
\text { Sexual/IDU }\end{array}$ & $\begin{array}{c}103 \\
3\end{array}$ & $\begin{array}{c}68.7 \\
2.0\end{array}$ & $\begin{array}{l}6.8 \\
8.7\end{array}$ & $\begin{array}{l}1.6 \\
2.1\end{array}$ & 0.132 \\
\hline & Mixed & 3 & 2.0 & 5.7 & 0.6 & \\
\hline
\end{tabular}

Note: * Non-representative categories were excluded from the analysis/t: $t$-test. 
Table 3 - Influence of factors on risk according to logistic regression, João Pessoa, Paraíba, Brasil, 2012

\begin{tabular}{|c|c|c|c|c|c|c|}
\hline \multirow[t]{2}{*}{ Factor } & \multirow[t]{2}{*}{ Category* } & \multirow[t]{2}{*}{ B } & \multirow[t]{2}{*}{$p$ value } & \multirow[t]{2}{*}{ Odds } & \multicolumn{2}{|c|}{$\begin{array}{l}\mathrm{Cl} \text { of } 95 \% \text { for } \\
\text { Odds ratio }\end{array}$} \\
\hline & & & & & Inf & Sup \\
\hline Sex & Male & 0.784 & 0.344 & 2.19 & 0.43 & 11.12 \\
\hline \multirow[t]{2}{*}{ Age range } & $40-59$ & -0.081 & 0.903 & 0.92 & 0.24 & 3.40 \\
\hline & $60-71$ & 0.999 & 0.496 & 2.72 & 0.15 & 48.38 \\
\hline \multirow[t]{2}{*}{ Skin color } & Black & -0.347 & 0.703 & 0.71 & 0.11 & 4.20 \\
\hline & Brown & 1.713 & 0.023 & 5.55 & 1.26 & 24.36 \\
\hline \multirow[t]{2}{*}{ Marital status } & Married/Common-law marriage & -0.757 & 0.300 & 0.47 & 0.11 & 1.96 \\
\hline & Separated/divorced & 1.312 & 0.269 & 3.71 & 0.36 & 38.06 \\
\hline \multirow[t]{3}{*}{ Schooling } & Elementary & -1.820 & 0.108 & 0.16 & 0.01 & 1.49 \\
\hline & High school & -1.277 & 0.314 & 0.28 & 0.02 & 3.35 \\
\hline & College & -3.744 & 0.029 & 0.02 & 0.00 & 0.68 \\
\hline \multirow[t]{3}{*}{ Employment status } & Retired/pensioner & 0.252 & 0.759 & 1.29 & 0.25 & 6.42 \\
\hline & Sick leave & 2.804 & 0.040 & 16.51 & 1.13 & 240.92 \\
\hline & Unemployed & 0.938 & 0.418 & 2.55 & 0.26 & 24.72 \\
\hline \multirow[t]{3}{*}{ Economic class } & $\mathrm{C}$ & 2.999 & 0.005 & 20.07 & 2.52 & 159.86 \\
\hline & $\mathrm{D}$ & 3.976 & 0.004 & 53.32 & 3.65 & 777.57 \\
\hline & $E$ & 22.750 & 0.999 & $7.58 \times 10^{9}$ & 0.00 & - \\
\hline \multirow[t]{2}{*}{ Sexual orientation } & Homosexual & 1.429 & 0.172 & 4.17 & 0.53 & 32.43 \\
\hline & Bisexual & -1.197 & 0.246 & 0.30 & 0.04 & 2.27 \\
\hline Transmission & Sexual & 0.288 & 0.692 & 1.33 & 0.32 & 5.56 \\
\hline
\end{tabular}

Note: *The categories not cited in the table consist in comparable groups; B - Estimate of the parameters of the Logistic Regression model

The logistic regression model showed that brown individuals were five times more likely to be in the risk category than white ones (comparable group); individuals on sick leave were 16 times more likely to belong to the risk group compared to employed or self-employed ones; and individuals in classes C and D were respectively 20 and 53 times more likely to be in the risk group than those in class B (comparable group). The results also indicated that individuals with higher schooling (college) were $98 \%$ less likely to be in the risk group as compared to those without any degree of education; thus, higher schooling acts as a protection factor for the investigated outcome (Table 3).

\section{DISCUSSION}

The sociodemographic and clinical profiles are similar to those observed in Brazil and the world, with a predominance of males, heterosexuals, individuals with low economic power and schooling, and with better clinical and immunological indicators after treatment ${ }^{(2,9-11)}$. In addition to the expression of such consonance, this profile should be analyzed considering the risk of exacerbations, instability of clinical conditions capable of leading to death, since AIDS is an incurable disease and is currently recognized as the fifth cause of death in adults of low income countries ${ }^{(10)}$.

The prediction of intervening factors on the risk of these phenomena can guide the care offered to people in outpatient follow-up, especially in regions where there is a trend of increased AIDS mortality in the last ten years, particularly among people aged 55-59 years included in the prevalent age range of the study ${ }^{(11)}$.

It is known that the development of AIDS and its complications involves pathophysiological phenomena that result in increased viremia, immune suppression and susceptibility to opportunistic diseases, whose clinical expressions are given through TLCD4+ count, quantification of plasma VL and various clinical manifestations ${ }^{(9)}$.

TL-CD4+ counts are markers of the immunological situation, indicative of response to HAART and predisposition to opportunistic infections ${ }^{(2,9)}$; recognized as the main prognostic indicator of the evolution of the disease and the survival of the infected ${ }^{(3)}$. Regarding VL, although there is no scientific evidence of its correlation with mortality, it is a marker of the evolution of the infection, and analyzed in conjunction with TL-CD4+ (with which it expresses an inverse behavior), it aids in the identification of virological failure in treated persons; in addition to studies on quality of life indicating association of detectable VL results with worse scores in the physical domain ${ }^{(4,9,12-13)}$.

Due to immunocompromising, the occurrence of opportunistic diseases contributes to the increase of hospitalizations and deaths related to the disease, reducing the survival and quality of life of infected individuals, even after the institution of ART ${ }^{(14)}$. In addition, there is evidence that treatment of opportunistic and chronic diseases may interfere with antiretroviral tolerance, increasing the risk of toxicity, which needs to be considered in the management and control of specific pharmacotherapy ${ }^{(13)}$.

In addition to the isolated analysis of the mentioned indicators, the proposed score quantifies in a single variable the set of clinical situations and immunological condition that predispose to opportunistic infections, or the use of a greater number of medications, which represent a risk of exacerbation of the clinical conditions of people living with HIV/AIDS.

The understanding that detectable VL, low TL-CD4+, greater number of opportunistic diseases, more chronic diseases and more clinical manifestations increase the risk score, and that the 
presence of opportunistic diseases and clinical manifestations (of any nature and origin) contributes to the classification of users into this group, can guide the professionals of the specialized service that participate in the follow-up of these cases to consider these indicators in the planning of preventive actions of unfavorable clinical outcomes, through the mobilization of more appropriate resources to each situation.

These indicators can, therefore, instrumentalize the nurses' work process, so as to restructure the practice for the provision of specific care, capable of increasing visibility and professional recognition ${ }^{(15)}$; in addition to qualifying nursing care for the production of network care, given the recognition that no professional and service has all the resources adequate to meet the demands in this direction ${ }^{(6)}$.

Supported by a predictive technology of clinical risk, the specialized service professionals, among them the nurse, will be able to seek articulation with primary care services, which, owing to their foundations present great potential in the prevention and management of complications and injuries in the diverse sanitary contexts, due to facilitated access and centralization of care to assigned users ${ }^{(16-17)}$. They can also articulate with social actors, such as NGOs/AIDS, which represent the action of organized civil society, historically configured as a social force in the struggle for the promotion of democracy, social justice and guarantee of rights ${ }^{(18)}$.

For the nurse, in particular, the clinical risk classification can contribute to the prediction of human responses associated with the exacerbation of the disease (indicative of nursing diagnoses) ${ }^{(14)}$, thus contributing to the systematization of care, focusing on the subjects and their needs and proactive action in the design and monitoring of the care plan. Thus, risk classification can support the expression of the clinical nursing practice in specialized care for people living with AIDS and thus contribute to coping with a fragility in this level of care, identified in a national study ${ }^{(19)}$.

The influence of employment situation and economic class on the risk reaffirm the intervention of socioeconomic conditions on health and corroborate a study that identified employment as an indicator associated with improvement of immunological conditions in treated persons ${ }^{(12)}$ and work as a strategic element for the improvement of the health status of people living with HIV/AIDS ${ }^{(20)}$.

In addition to the financial aspects involved in the guarantees of good quality food, transport to go to routine consultations and to purchase other medicines, the fact that individuals who are on sick leave present a higher risk than unemployed ones draws attention to the therapeutic potential of work. In this regard, it is known that social life and relations contribute positively to the psychic confrontation of the problems intrinsic to living with infection/illness ${ }^{(9,21)}$, whose repercussions tend to be harmful in several dimensions of health, including the physical one.

These findings justify the fact that working/self-employed people constitute a group with lower clinical risk, since they are in better financial and relational conditions as compared to the other categories; and emphasize the importance of the expansion of public policy and precautionary actions towards addressing stigma and discrimination in the working environment and strengthening intersectoriality in this regard ${ }^{(9)}$.
Regarding the organizational dimension of care, the confrontation of the asymmetric relationships between work routines, routine clinical treatment/follow-up, and the health conditions experienced by people living with HIV/AIDS, as indicated by another national study, would involve the reorganization of hours of service of the health services ${ }^{(9)}$.

Despite the brown color and its interface with risk, it is known that, in 2012, this concentrated the second highest prevalence among people living with HIV/AIDS in Brazil, even among men, with a tendency to increased cases among whites and browns in the last ten years ${ }^{(22)}$. In addition, people who declared themselves to be brown in the last Census correspond to $52 \%$ of the Paraíba population ${ }^{(23)}$.

A Brazilian study in the South and Southeast regions suggests that brown and black populations are factors that decrease survival in people with AIDS, a phenomenon related to inequalities in access to education and health services, exposure to other diseases and differences in living conditions ${ }^{(24)}$.

Risk stratification is a recognized resource in the organization of care to acute conditions, with the potential to improve the quality, experience and costs of care to people with chronic conditions ${ }^{(7)}$, such as those living with the infection or manifest AIDS, whose care can reduce the chances of illness, mortality, transmission of the virus, in addition to improving the quality of life of these people ${ }^{(25)}$.

\section{Limitations of the study}

Despite the relevance of the obtained results, the crosssectional design and the non-probabilistic sampling reduce their analytical soundness and generalization power, which can be recognized as limitations of the study. Therefore, these results encourage the development of analytical studies aimed at the construction of instruments and the exploration of other indicators that contemplate the specificities of people with HIV and on follow-up, so that there is support for decisions towards the production of universal, equal and effective care to people living with HIV/AIDS.

\section{Contributions to the area of nursing, health or public policy}

The score proposed from the clinical indicators (TL-CD4+, VL, clinical manifestations, opportunistic and chronic diseases) and its association with sociodemographic variables may contribute to the qualification of the clinical and managerial performance of nurses, especially in specialized HIV care, in which it is recognized that there is a need for all professionals involved in care to work hard so that their actions positively influence the lives of the people on follow-up ${ }^{(14)}$, in a perspective of offering interprofessional and interdisciplinary care, necessary to coping with the disease.

\section{CONCLUSION}

Regarding the clinical indicators that supported the construction of the score, we observed the influence of high TL-CD4+ counts and undetectable viral load for the classification in the non-risk group and the influence of the presence of opportunistic 
diseases and clinical manifestations in the classification of the risk group. Regarding sociodemographic aspects, there were significant differences in the mean risk according to employment status, economic class and skin color, especially for the group of sick leave, economic classes $C$ and $D$, and brown population as conditions that increase the chances of risk of clinical instability.

The influence of clinical indicators (analyzed in combination) and of social interface on the risk of undesirable (potentially avoidable) outcomes points to the need of increasing the focus of specialized care beyond the mobilization of technical resources for the implementation of HAART, isolated monitoring of immunological indicators, and focus on clinical management of conditions already installed.

These results may support the planning of teaching, research and extension actions capable of eliciting the instrumentalization of specialized services and, especially, the clinical practice of the nurse, for: the planning of actions/services in line with the vulnerabilities that course with the clinical complications of the subjects on follow-up; decision-making inherent to the articulation with other services/departments; and creation of protocols and flows, fundamental to the qualification of care in the care network and provision of equal care.

\section{REFERENCES}

1. Mendes EV. As redes de atenção à saúde. Brasília, DF: Organização Pan-Americana da Saúde; 2011.

2. Ministério da Saúde (BR). Secretaria de Vigilância em Saúde. Departamento de DST, Aids e Hepatites Virais. Protocolo clínico e diretrizes terapêuticas para manejo da infecção pelo HIV em adultos. Brasília, DF; 2013.

3. Nunes AA, Caliani LS, Nunes MS, Silva AS, Mello LM. Profile analysis of patients with HIV/AIDS hospitalized after the introduction of antiretroviral therapy. Ciênc Saúde Coletiva [Internet]. 2015 [cited 2016 Nov 30];20(10):3191-8. Available from: http://www.scielo.br/pdf/csc/ v20n10/en_1413-8123-csc-20-10-3191.pdf

4. Tancredi MV, Waldman EA. Survival of AIDS patients in Sao Paulo-Brazil in the pre-and post-HAART eras: a cohort study. BMC Infect Dis [Internet]. 2014 [cited 2015 Nov 30];14(1):599. Available from: http://www.ncbi.nlm.nih.gov/pmc/articles/PMC4247874/pdf/12879_2014_ Article_599.pdf

5. Joint United Nations Program on HIV/Aids. 90-90-90: an ambitious treatment target to the help end the AIDS epidemic. Geneva: Unaids; 2014.

6. Joint United Nations Program on HIV/Aids. Unaids data 2017. Geneva: Unaids; 2017.

7. Lewis GH. Next steps for risk stratification in the NHS. NHS England [Internet]. 2015 [cited 2015 Aug 25]. Available from: https://www. england.nhs.uk/wp-content/uploads/2015/01/nxt-steps-risk-strat-glewis.pdf

8. Associação Brasileira de Empresas de Pesquisa. Critério de Classificação Econômica Brasil: 2010 [Internet]. São Paulo: Abep; 2010 [cited 2015 Abr 20]. Available from: http://www.abep.org/criterioBrasil.aspx

9. Ferreira BE, Oliveira IM, Paniago AMM. Qualidade de vida de portadores de HIV/AIDS e sua relação com linfócitos CD4+, carga viral e tempo de diagnóstico. Rev Bras Epidemiol [Internet]. 2012 [cited 2015 Aug 25];15(1):75-84. Available from:: http://www.scielo.br/pdf/rbepid/ v15n1/07.pdf

10. World Health Organization. The top 10 causes of death, 2015 [Internet]. Geneva:WHO; 2017 [cited 2017 Jul 12]. Available from: www.who. int/mediacentre/factsheets/fs310/en/

11. Ministério da Saúde (BR). Secretaria de Vigilância em Saúde. Boletim epidemiológico - Aids e DST: Ano Il, n 1, até semana epidemiológica 26a - dezembro de 2013. Brasília, DF; 2013.

12. Chow JY, Alsan M, Armstrong W, del Rio C, Marconi VC. Risk factors for AIDS-defining illnesses among a population of poorly adherent people living with HIV/AIDS in Atlanta, Georgia. AIDS Care [Internet]. 2015 [cited 2015 Aug 25];27(7):844-8. Available from: https://www. ncbi.nlm.nih.gov/pmc/articles/PMC4400213/pdf/nihms658180.pdf

13. Lima DGL, Arruda EAG, Lima AJA, Oliveira BE, Fonteles MMF. Factors determining changes in initial antiretroviral therapy. Rev Assoc Med Bras [Internet]. 2012 [cited 2015 Aug 25];58(2):222-8. Available from: http://www.scielo.br/pdf/ramb/v58n2/en_v58n2a19.pdf

14. Silva RAR, Costa RHS, Nelson ARC, Duarte FHS, Prado NCC, Rodrigues EHF. Predictive factors for the Nursing Diagnoses in people living with Acquired Immune Deficiency Syndrome. Rev Latino-Am Enfermagem[Internet]. 2016 [cited 2016 Aug 02];24:e2712. Available from: http:// www.scielo.br/pdf/rlae/v24/0104-1169-rlae-24-02712.pdf

15. Souza Neto VL, Silva RAR, Silva CC, Negreiros RV, Rocha CCT, Nobrega MML. Proposal of nursing care plan in people hospitalized with AIDS. Rev Esc Enferm USP [Internet]. 2017 [cited 2017 Jun 15];51:e03204. Available from: http://www.scielo.br/pdf/reeusp/v51/1980-220X-reeusp51-e03204.pdf

16. Norman AH, Tesser CD. Access to healthcare in the Family Health Strategy: balance between same day access and prevention/health promotion. Saúde Soc [Internet]. 2015 [cited 2016 Jun 25];24(1):165-79. Available from: http://www.scielo.br/pdf/sausoc/v24n1/en_01041290-sausoc-24-1-0165.pdf

17. Stokes J, Panagioti M, Alam R, Checkland K, Cheraghi-Sohi S, Bower P. Effectiveness of case management for "at risk" patients in primary care: a systematic review and meta-analysis. PLos ONE [Internet]. 2015 Jul [cited 2015 Nov 15];10(7):1-42. Available from: https://www.ncbi. nlm.nih.gov/pmc/articles/PMC4505905/pdf/pone.0132340.pdf

18. Mendonça $\mathrm{P}$, Alves MA, Nogueira F. Civil society organisations and the fight for rights in Brazil: analysis of an evolving context and future 
challenges. Dev Pract. 2016;26(5):592-605. doi: 10.1080/09614524.2016.1190318

19. Macedo SM, Miranda KCL, Silveira LC, Gomes AMT. Nursing care in specialized HIV/Aids outpatient services. Rev Bras Enferm [Internet]. 2016 [cited 2017 Jan 25];69(3):515-21. Available from: http://www.scielo.br/pdf/reben/v69n3/en_0034-7167-reben-69-03-0515.pdf

20. Liu Y, Canada K, Shi K, Corrigan P. HIV-related stigma acting as predictors of unemployment of people living with HIV/AIDS. AIDS Care. 2012;24(1):129-35. doi: 10.1080/09540121.2011.596512

21. Bulgarelli AF, Tavora PR. Aids and discrimination, the disease in the contextual labour environment. Cienc Cuid Saude [Internet]. 2013 [cited 2015 Jul 15];12(4):797-803. Available from: http://periodicos.uem.br/ojs/index.php/CiencCuidSaude/article/view/10919/pdf_101

22. Joint United Nations Program on HIV/AIDS. Global Report: Unaids report on the global AIDS epidemic 2013. Geneva: Unaids; 2013.

23. Instituto Brasileiro de Geografia e Estatística. Censo demográfico 2010 [Internet]. Brasília (DF); 2010 [cited 2015 Apr 28]. Available from: https://biblioteca.ibge.gov.br/biblioteca-catalogo?id=794\&view=detalhes

24. Guibu IA, Barros MBA, Donalisio MR, Tayra A, Alves MCGP. Survival of AIDS patients in the Southeast and South of Brazil: analysis of the 1998-1999 cohort. Cad Saúde Pública [Internet]. 2011 [cited 2015 Nov 30];27(Suppl-1):s79-s92. Available from: http://www.scielo.br/pdf/ csp/v27s1/09.pdf

25. Pinho CM, Damaso BFR, Gomes ET, Trajano MDFC, Andrade MS, Valença MP. Religious and spiritual coping in people living with HIV/ Aids. Rev Bras Enferm [Internet]. 2017 [cited 2017 Jun 30];70(2):392-9. Available from: http://www.scielo.br/pdf/reben/v70n2/0034-7167reben-70-02-0392.pdf 